\title{
Optimizing Reflective Practice Through Students' Dialogue Video \\ Recording to Improve \\ Students' Speaking Skill
}

\author{
Irene Femi Rahardiani, Dewi Rochsantiningsih, Endang Setyaningsih \\ English Education Department \\ Teacher Training and Education Faculty \\ Sebelas Maret University of Surakarta
}

Email: femi.irene@gmail.com

\begin{abstract}
This article describes an action research held at seventh grade students of a junior high school in Surakarta on the implementation of reflective practice through students' dialogue video recording to improve students' speaking skill. The research data are collected through observation, interview, questionnaire and speaking tests. The data are then analysed through the procedure of assembling, coding, comparing, building interpretations, and reporting the outcomes. The research findings point out that reflective practice through students' dialogue video recording improves students' speaking skill which including: 1) the students developed their vocabularies; 2) most of the students could pronounce in acceptable pronunciation; 3) many students could speak fluently without too many pauses or repetition; 4) students could correctly use the grammar and they could recognize the wrong and correct the grammar that had been taught. Besides, the students' mean score also improves from 34 in pre-test, 45 in test 1 and 64.5 in post-test.
\end{abstract}

Keywords: reflective practice, students' dialogue, video recording, speaking skill, action research.

\section{INTRODUCTION}

From all four basic language skills, speaking is regarded as a central skill (Bailey and Savage in Lazaraton, 2001). Furthermore, Lazaraton (2001: 103) stated "the ability to speak a language is synonymous with knowing that language since speech is the most basic means of human communication". It means that as a central skill, speaking has the most crucial role in daily communication. Watkins (2005) listed three reasons why people speak and how important speaking is, which include: 1) to maintain existing social relationship and to make new ones; 2) to pool and exchange information; and 3) to ease the performance of transactions. It is obvious that speaking has a very crucial role to connect people each other in daily life.

However, it was acknowledged through the pre research held on the seventh grade students in a junior high school in Surakarta that the students had low proficiency in speaking. The students were not able to speak in English well which was indicated from: (1) students' vocabularies were limited. The students did not know the meaning of certain words such as the word 'my' and 'scarf' and there was a student who said that he was only able to say 'yes' and 'no' in English; (2) several students frequently produced unacceptable pronunciation when they were speaking. Several students had poor pronunciation in 
regards to many words such as the word 'can' pronounced as $/ \mathrm{t} \int \Lambda \mathrm{n} /$ instead of $/ \mathrm{k} ə \mathrm{n} /$ or the word ' $\mathrm{I}$ ' pronounced as /i:/ instead of /aI/; (3) several students were not able to deliver the speech fluently. There were pauses and repetitions when several students answered the questions or reading a dialog; (4) most of the students were difficult to produce grammatically correct phrase or sentence. For example, one of them answered the teacher's question with "You is..." which then cut by the teacher and corrected whether it should be "You are...". Besides, the student's mean score in the speaking pre-test was 35 that was under the passing grade which is 60 .

There were four possible causes of the students' speaking skill problem: 1) most of the students did not pay much attention to the lesson. It was often found that most of the students did not pay attention to the lesson, for example one was busy playing with his scarf; 2) most of the students were easily distracted and often spoke or yelled about subject matter which was off topic; 3 ) several students were not interested due to the teacher's monotonous media. They got bored easily and then they did something else instead of listening to the teacher; 4) several students were not interested due to the teacher's assignments. They did not do the assignment immediately but they walked around the class and played around when they were asked to do the assignment.

In order to solve above problems, a solution was proposed by using reflective practice through students' dialogue video recording. This article discusses the findings of the action research conducted in a junior high school in Surakarta which answers the formulated questions: 1) Does the reflective practice through students' dialogue video recording improve the students' speaking skill? If yes, to what extent is its improvement?; 2) What are the strenghts and weaknesses of reflective practice through students' dialogue video recording when it is implemented in this research?

In order to solve above problems, a solution was proposed by using reflective practice through students' dialogue video recording. Reflective practice means that ones engage in a continuous cycle of selfobservation and self-evaluation in order to understand their own actions and the reactions they prompt in themselves and in others (Cunningham in Surgenor, 2011). In this research, the ones who did the reflective practice were the students. Furthermore, Osterman and Kottkamp (1993) said that reflective practice can develop a greater level of self-awareness about the nature and impact of one's performance. This awareness creates opportunities for growth and development. These experts (1993: 2) explained more concerning the awareness of reflective practice:

“... awareness is essential for behavioral change. To gain a new level of insight into personal behavior, the reflective practitioner assumes a dual stance, being, on one hand, the actor in a drama and, on the other hand, the critic who sits in the audience watching and analyzing the entire performance. To achieve this perspective, individuals must come to an understanding of their own behavior; they must develop a conscious awareness of their own actions and effects and the ideas or theories-in-use that shape their action strategies."

It could be seen on the above theory that awareness in reflective practice is needed in order to gain a new level of insight into personal behavior particularly the students who do the reflective practice. The awareness can come from two parties, the one who did the performance who 
needed an evaluation and the others who also analyze and evaluate the performance.

In order to make analyzing and evaluating of the performance easier, there are some media provided to help the process of analyzing and evaluating. Department for education and skills (2007) suggested ten media that can be used, they are continuous prose, notes, annotated diagrams, tables, ediscussions with a peer, brainstorming, mind maps, flow charts, reflective log questions, audio or video recording. Video recording, was chosen because it tended to give a clear vision for analyzing and evaluating purpose.

Furthermore, Kirkgoz (2011) stated three advantages on integrating video recording of student speaking in language learning are: (1) the students and their fellow friends' performances can be watched and seen by themselves; (2) the video can be used by teachers to help students becoming better speakers in English; (3) the students have the opportunity to view the video recording more that once to make self-evaluation of themselves as well as their fellow friends. Besides, video recording is possible conducted through the widespead availability of relatively inexpensive video cameras (Hall, 2007). Shrosbree (2008) added that using relatively inexpensive equipment and easily acquired skills, teachers and learners can utilise a wide range of effective and motivating video methodologies.

The curriculum applied in the junior high school which was being the research subject, is Kurikulum Tingkat Satuan Pendidikan (KTSP) or school-based curriculum. It is explained in the curriculum that the competency standard of junior high school students is "Mengungkapkan makna dalam percakapan transaksional dan interpersonal sangat sederhana untuk berinteraksi dengan lingkungan terdekat" which means that the students are expected to be able to express meaning in simple transactional and interpersonal dialogue to interact with surroundings. It means that the students are prepared to be able to interact with people as the final aim. Meanwhile, Brown (2001: 267) stated "the benchmark of successful language acquisition is almost always the demonstration of an ability to accomplish pragmatic goals through interactive discourse with other speakers of the language". It means that the students must be facilitated with learning and teaching activity to support students in practicing interaction. Thus, it was proposed a solution by using dialogue, which facilitated an interaction, to practice English speaking skill.

Furthermore, Brown in Ghanim \& Khalaf (2012) mentioned the advantage of using dialogue when teaching a language is that the people learning are not only able to understand the words of the foreign language, but also understand the correct language rules. Brown's statement is reinforced by the statement of Broughton, Brumfit, Flavell, Hill and Pincas (2003) who said that dialogue represents the practice of phonological, lexical and grammatical items. These statements convince that the use of dialogue is beneficial in improving students speaking skill. In addition, particularly for the beginners or less confident learners, the dialogue is a good way to get learners to practice saying utterances in the target language without hesitation and within a wide variety of contexts; and learning by heart increases the learner's vocabulary of ready-made combinations of words or 'formulae' (Ur, 1996).

Clandfield (2003) said that dialogues are often used to introduce learners to a new structure or functions, for example, complaining in a restaurant. Students listen to a dialogue usually on a cassette or video, 
and copy it with partner. These dialogue sources help the students to learn how the dialogue is, especially when it is in the form of video. Thus, it came up an idea to record the dialogue activity of the students onto video called video recording. Video recording could be an option of teaching aid used to support the dialogue technique in improving students' speaking skill. Moreover, this kind of technique and media is also purposed to motivate the students in learning English especially speaking which usually had boring lesson.

Reflective practice through students' dialogue video recording has several advantages and positive reasons to support the teaching and learning English, particularly speaking. Thus, reflective practice through students' dialogue video recording is expected to be able to overcome the students' problems of speaking and improve the speaking skill of seventh grade students in a junior high school in Surakarta.

\section{RESEARCH METHODS}

The method used in this research was action research. The following is the definitions of action research according to the experts. Bailey (2001) argued that action research is an approach to collecting and interpreting data that involves a clear, repeated cycle of procedures. The procedures are planning an action, action, systematic observation of the outcomes of the action, reflecting the action, planning a subsequent action and then the cycle begins again.

On the other hand, Kemmis and McTaggart in Bailey (2001: 490) stated that action research is:

"A form of self-reflective enquiry undertaken by participants in social situations in order to improve the rationality and justice of their own social or educational practices, as well as their understanding of these practices and the situations in which these practices are carried out."It can be seen that there is a case in a social or education practice that needs to improve both the rationality and justice of the social or education practices, and the understanding of the practices and situations of the research. Similar thing expressed by Ur (1996) who said that action research is meant primarily to improve the teacher-researcher's own teaching. It is usually done by two or more collaborating teachers based on a cycle of investigation, action and reinvestigation.

From the previous definitions, action research is an approach of self-reflective to improve the rationality and justice of the participants' social or educational practices that involves clear, repeated cycle of procedures. This research is conducted based on a case in a social or education practice. The cycle of procedures are from planning an action, action, systematic observation of the outcomes of the action, reflecting the action, and then the procedures repeated again.

Burns (1999) divided two ways of collecting data called observational and nonobservational techniques. This research required the both techniques. The observational techniques include observation, field notes, teacher journals, and photographs. Meanwhile, nonobservational techniques are interview, questionnaires, and documents. The data are then analysed through the procedure of: assembling, coding, comparing, building interpretations, reporting the outcomes.

This research was conducted in two cycles. Cycle 1 consisted of three meetings which involve five procedures: planning the action, implementing the action, observing the action, reflecting the result, and revising the plan. Whereas cycle 2 consisted of two 
meetings which involve four procedures: planning the action, implementing the action, observing the action, and reflecting the result.

\section{RESEARCH FINDINGS AND DISCUSSIONS}

It was found in the pre research that the seventh grade students in a junior high school in Surakarta had low proficiency in speaking. The students' speaking skill needed to be improved by implementing teaching techniques or using media which could help the teacher and students to overcome the problems. The teacher said in the pre research interview that the students were more enthusiastic with the English lesson, particularly when learning spoken English, when using a learning media. Thus, I used reflective practice through students' dialogue video recording to improve students' speaking skill. The implementation of the research was conducted in two cycles consisted of cycle 1 and cycle 2 . problems found during the pre-research. The second stage that was implementing the action was done by implementing all the plans in the class through teaching and learning process. The third stage, observing the action, was done during implementation of the action. In this stage, the students' behavior was observed. The next stage was reflecting on the result of the observation. The final stage was revising the plan which was done after deciding that it was needed to hold the next cycle based on the results of the reflection stage.

In overall, cycle 1 findings showed that reflective practice through students' dialogue video recording could attract students' attention to the lesson and their interest in doing the assignments. They also were able to see their strengths and weaknesses when they were speaking. By knowing the strengths and weaknesses, the students were able to know which part of speaking skill that they needed to improve and which part of speaking skill that they

Table 1 Students' Improvement after Cycle 1 Implementation Analyzed from Accuracy and Fluency Mean Score

\begin{tabular}{|c|c|c|c|}
\hline & Pre-test & Test 1 & Improvement \\
\hline $\begin{array}{l}\text { Accuracy } \\
\text { Mean Score }\end{array}$ & 17,25 & 23 & 5,75 \\
\hline $\begin{array}{l}\text { Fluency } \\
\text { Mean Score }\end{array}$ & 16,75 & 22 & 5,25 \\
\hline Mean Score & 34 & 45 & 11 \\
\hline
\end{tabular}

The first stage of the activity in cycle 1 was planning the action which included preparing lesson plans and materials. The lesson plans consisted of several learning activities using reflective practice through students' dialogue video recording. The learning activities, such as drilling, making dialogue, recording the students' dialogue onto a video, discussing students' video recordings, were directed to solve the needed to keep. The improvement of students' speaking skill mean score analyzed from accuracy and fluency after cycle 1 implementation is described in table 1.

It could be seen through the above table that the students speaking skill improved. In measuring the students' speaking skill, the scoring was categorized into two main indicators: 1) accuracy which contained of vocabulary, grammar, and 
pronunciation and 2) fluency. In the preresearch, it was found that the students had problems in their vocabulary, pronunciation, fluency and grammar of their speaking skill. After cycle 1 implementation, the students showed improvements of each problem indicators. There were also other data supported the students' improvements and the effect of reflective practice through students' dialogue video recording implementation beside the test result.

The data collected through the observation showed that there were improvements of the students' speaking skill seen from the indicators: 1) vocabulary. Most of the students got new vocabularies from the given materials. Many of the students could guess the meaning of a phrase or sentence after knowing the meaning of certain words; 2) pronunciation. Many of the students could pronounce in acceptable pronunciation of the expressions that they had learned. They could correct their friend's unacceptable pronunciation; 3) fluency. Several students were more fluent in speaking than before. They could deliver speech without too many pauses. Most of the students did not do repetition; 4) grammar. Most of the students could correctly use the grammar that had been taught.

Beside the students' speaking skill that improved, the students' behavior also changed. The students' behavior changed becoming better than in the pre-research. Most of the students paid much attention to the lesson particularly when watching the video and the video recordings. They also spoke in the right time and context that was when the teacher gave questions or asked them to give comments. They showed interests toward the lesson that was when the teacher used video and video recording as the teaching media. Additionally, many of the students interested in doing the assignment, which was seen from many of the students volunteered themselves to perform in front of the class.

However, there were also found several weaknesses related to students' speaking skill and students' behavior that need to be solved. Therefore, I thought that it was necessary to conduct the next cycle with a revised plan in order to overcome the weaknesses. It was also needed to solve the problems appeared in cycle 1. Before conducting the next cycle, the causes of the problems were identified to find the solutions which then the solutions would be implemented in the next cycle.

The weakenesses found in cycle 1 were about many of the students who still had some problems with their speaking skill. Most of the students forgot the meaning of certain words particularly when doing the task. They kept asking again the meaning of certain words found in the task because they already forgot the meaning of words after it was explained. In order to help them to be able to guess and remind them of the words meaning, I proposed a solution by showing some illustrations that illustrated the situation found in the task. If the students asked the meaning of certain words, I could show them the illustrations so that they could guess the words meaning.

The students' fluency was not improved a lot. Many of the students still could not speak fluently. Thus, I thought that students needed more activities to improve their fluency that was through giving more drillings than in the cycle 1 . I proposed a planned by giving more drillings and drillings through games. Besides, the students could also do more practices of their pronunciation by doing more drillings. I would also use Longman Pronunciation Dictionary so that when the students found a difficult word to pronounce, I could show them a model of acceptable pronunciation. 
In addition, the pronunciation model in the Longman Pronunciation Dictionary could be repeated as many times as possible.

The students had difficulty in making dialogue without writing it first. They wrote down the dialogue first and then practiced it. In the next cycle, I would ask the students to make the dialogue without writing it first in order to accustom the students to be able to speak spontaneously. Thus, the students would develop their speaking skill as well instead of speaking limited from the textbook.

In order to overcome the weaknesses found in cycle 1 , the action plan of cycle 2 was revised and developed from the action plan of cycle 1 . The action plan of cycle 2 was almost the same as action plan of cycle 1. It was planned that cycle 2 conducted in they also practiced to act the dialogue added with some properties to support their performances. In addition, the students' achievement seen from the mean score also improved significantly. The improvement of students' speaking skill mean score analyzed from accuracy and fluency after cycle 1 implementation is described in table 2 .

It could be seen from the above table that there were significant improvements of students speaking skill particularly the subskills seen from the two indicators that were 1) accuracy, which contained of vocabulary, grammar, and pronunciation and 2) fluency. Furthermore, the students' speaking skill which became the problems found in the pre-research that needed to improve were vocabulary, pronunciation, fluency and grammar. The test result of

Table 2 Students' Improvement after Cycle 2 Implementation Analyzed from Accuracy and

\begin{tabular}{lccc}
\multicolumn{4}{c}{ Fluency Mean Score } \\
\hline & Test 1 & Post-test & Improvement \\
\hline $\begin{array}{l}\text { Accuracy } \\
\text { Mean Score }\end{array}$ & 23 & 33 & 10 \\
$\begin{array}{l}\text { Fluency } \\
\text { Mean Score }\end{array}$ & 22 & 31,5 & 9,5 \\
Mean Score & 45 & 64,5 & 19,5 \\
\hline
\end{tabular}

two meetings.

After cycle 2 implementation, it was found that there were many improvements of the students' speaking skill more than it was found in the cycle 1 . Since the cycle 2 was held to overcome the weaknesses found in cycle 1, the speaking subskills that became the weaknesses in cycle 1 were becoming the improvements focus. Furthermore, each subskill had its own improvements. Beside the students' speaking skill, the students' behavior was also developed. For example, the students were not only performing their dialogue but cycle 2 above showed that each problem indicators had its improvements. Beside the test result, significant improvements after implementing cycle 2 which the treatment was revised, were also found from other data that is explained in the following.

The data collected through the observation showed that there were improvements of the students' speaking skill seen from the indicators: 1) vocabulary. Students got new vocabularies from the materials. Several students developed their dialogue by using new vocabularies or phrases which was not only found in the 
given materials. Most of the students could guess the meaning of a phrase or sentence after knowing the meaning of certain words. They knew and still remembered the meaning of certain words that they had known in the previous meeting. Most of the students could guess the meaning of certain words after seeing the illustrations of the situation given on the task; 2) pronunciation. Most of the students could pronounce in acceptable pronunciation of the expressions that they had learned and they could recognize and correct their friend's unacceptable pronunciation; 3) fluency. Many students spoke more fluent than in cycle 1 . They could deliver speech without too many pauses. Most of the students did not do repetition; 4) grammar. Most of the students could correctly use the grammar that had been taught, they seemed not found any difficulties in understanding the grammar explanation, and they could recognize the wrong grammar and corrected it.

Beside affecting the students' speaking skill, the treatment of cycle 2 which was revised, were also affecting the students' behavior. The students showed behavior changes after implementing the new treatment. Students paid much attention to the lesson particularly when watching the video and video recordings and they also paid much attention the teacher's explanations for example when explaining the games. Most of the students spoke in the right time and context that was when the teacher gave questions or asked them to give comments and when they did drillings and played the game. They showed interests toward the lesson particularly when the teacher used the teaching media. For example, when the teacher used video and video recording or when the teacher used cards and soft ball to play the games and also when the teacher showed the illustrations through the slideshow during the teaching and learning process. Most of the students interested in doing the assignment which proven by volunteering themselves to perform in front of the class. They competed each other when doing the task or certain activity. They also did their task totally.

\section{CONCLUSIONS AND SUGGESTIONS}

After analyzing the result of the action research, it is concluded that the use of reflective practice through students' dialogue video recording improve students' speaking skill. The cycle 1 activities were directed to solve problem indicators found during the pre-research. The result of cycle 1 implementation showed that there were some improvements of the students' speaking skill including vocabulary, pronunciation, fluency and grammar. However, the result of cycle 1 did not show a significant result. There were several problems of students' speaking skill particularly the vocabulary, pronunciation and fluency. Thus, I revised the plan of cycle 2 that was focused on solving the speaking skill problems and other problems appeared in cycle 1 . The result of cycle 2 implementation was that the students showed significant improvements of their speaking skill. In overall, after implementing the research, the students improved their speaking skill which included: 1) the students developed their vocabularies; 2) most of the students could pronounce in acceptable pronunciation; 3) many students could speak fluently without too many pauses or repetition; 4) students could correctly use the grammar and they could recognize the wrong and correct the grammar that had been taught. Furthermore, the students' improvement of speaking skill also can be seen from the result of the students' speaking test which got 
improvement on their mean score in every cycle. The students' mean score in the pretest was 34 which contained of accuracy mean score that was 17.25 and fluency mean score that was 16.75. The mean score increased to 45 in the test 1 which contained of accuracy mean score that was 23 and fluency mean score that was 22 , and the mean score increased up to 64.5 in the posttest which contained of accuracy mean score that was 33 and fluency mean score that was 31,5 .

Besides, the implementation of the action also affected the students' behavior. In overall, the students' behavior improved during teaching and learning process. During the implementation of the action, the students paid much attention to the lesson particularly when watching the video and the students' video recordings. They spoke in the right time and context. They also showed interests toward the lesson and the assignment given by the teacher.

There were found seven strengths and four weaknesses of reflective practice through students' dialogue video recording when it is implemented in this research. The strengths are: 1) the technique and media improve the students' speaking skill. 2) It attracts most of the students' attention to the lesson. 3) The activities facilitate students to speak in the right time and context, 4) The technique and media attract most of the students' interest to the lesson and assignment. 5) The activities are enjoyable and fun. 6) The technique and media facilitate students in doing evaluation. 7) The technique encourages students to make dialogue orally.

However, there were four weaknesses of reflective practice through students' dialogue video recording which include: 1) the technique cannot work well without other supporting activities. 2) Video recording activity cannot work well in noisy situation. 3) There is potential technical problem using video recording. 4) The media needs various tools to support the activities.

In addition, I would like to give some suggestions related to this research for those who are closely related to English teaching and learning. These suggestions are expected to be beneficial, praticularly for students, teachers, institutions, and other researchers.

I suggest that the students should realize that learning is not only inside the classroom. They should maximize the usage of the technology around them which can be very beneficial. For example, the students can record their English speaking performance using their mobile phone which can record onto video. Through the video recordings, they can reflect on their performance and find the strengths or weaknesses of their English speaking skill.

English teachers should learn more concerning reflective practice through books or articles which can be found in the library or download it on the internet. The teachers should often use interesting teaching technique and media to attract students' attention to the lesson. They also should learn about how to use video recording equipments to get a good video recording which can be seen together with the students in order to let them do the reflective practice.

The other researchers should learn more about reflective practice and the techniques which are used to develop reflective practice. The researchers should know how to use the video recording tool before they use it. They should develop more on the students' dialogue activity.

Furthermore, I suggest for the schools to provide supporting facilities to use video recording as the teaching media. The schools check the equipments used to 
support teaching and learning process, to be always in a good condition. It is better if the schools add the number of equipments so that the teachers can use it anytime without waiting to other teachers. In addition, some experts should be invited at school to give some workshops or training for the teachers so that the teachers will enrich their knowledge, particularly about the technology to support the teaching and learning process.

\section{BIBLIOGRAPHY}

Bailey, K. M. (2001). Action Research, Teacher Research, and Classroom Research in Language Teaching. In M. Celce-Murcia (Ed.), Teaching English as a Second or Foreign Language Third Edition (pp. 489498). Boston: Heinle \& Heinle.

Broughton, G., Brumfit, C., Flavell, R., Hill, P., and Pincas, A. (2003). Teaching English as a Foreign Language Second Edition. Taylor \& Francis eLibrary.

Brown, H. D. (2001). Teaching by Principles: An Interactive Approach to Language Pedagogy Second Edition. Michigan: Longman.

Clandfield, L. (2003). Dramatic Dialogues that can be used in the Classroom. Macmillan Publishers Ltd. Retrieved from www.onestopenglish.com

Curtis, R., Webb-Dempsey, J., \& Shambaugh, N. (2010). Understanding Your Data. In R. P. Pelton (Ed.). Action Research for Teacher Candidates (pp. 27-57). Maryland: Rowman \& Littlefield Education.

Department for Education and Skills. (2007). Improving Speaking and Listening Skills: a practical guide for Skills for Life teachers. Nottingham: DFES Publications.

Ghanim, R. \& Khalaf, M. A. O. N. (2012). Using Cued-Dialogue and Gap
Filling Exercises to Develop Iraqi EFL Learners' Ability of Speaking. Al-Fatih Journal, 50, 1-21. Retrieved from http://www.iasj.net/iasj?func=fulltext \&aId $=61273$

Hall, R. (2007). Strategies for Video Recording: Fast, Cheap, and (mostly) in Control. In S. J. Derry. (Ed.), Guidelines for Video Research in Education: Recommendations from an Expert Panel (pp. 4-14). Chicago: Data Research and Development Center. Retrieved from http://drdc.uchicago.edu/what/videoresearch-guidelines.pdf

Kirkgoz, Y. (2011). A Blended Learning Study on Implementing Video Recorded Speaking Tasks in TaskBased Classroom Instruction. The Turkish Online Journal of Education Technology. 10(4), 1-13. Retrieved from http://www.tojet.net/articles/v10i4/10 41.pdf

Lazaraton, A. (2001). Teaching Oral Skills. In M. Celce-Murcia (Ed.). Teaching English as a Second or Foreign Language Third Edition (pp. 103115). Boston: Heinle \& Heinle.

Osterman, K. F. \& Kottkamp, R. B. (1993). Reflective Practice for Educators: Improving Schooling through Professional Development. California: Corwin Press, Inc.

Shrosbree, M. (2008). Digital Video in the Language Classroom. The JALT CALL Journal, 4(1), 75-84. Retrieved from http://journal.jaltcall.org/articles/4_1 _Shrosbree.pdf

Silfia, N. and Narius, D. (2012). VideoRecording based on Self Assessment System for Senior High School Students in Speaking Class. Journal of English Language Teaching, 1 (1), 153-160. Retrieved from http://ejournal.unp.ac.id/index.php/je 1t/article/view/922 
Surgenor, P. (2011). Tutor, Demonstrator \& Coordinator Development at UCD: 1. Reflective Practice. Retrieved from www.ucd.ie/t4cms/Reflective\%20Pra ctice.pdf

Ur, P. (1996). A Course in Language Teaching. Cambridge: Cambridge University Press.

Watkins, P. (2005). Learning to Teach English. Surrey: Delta Publishing. 